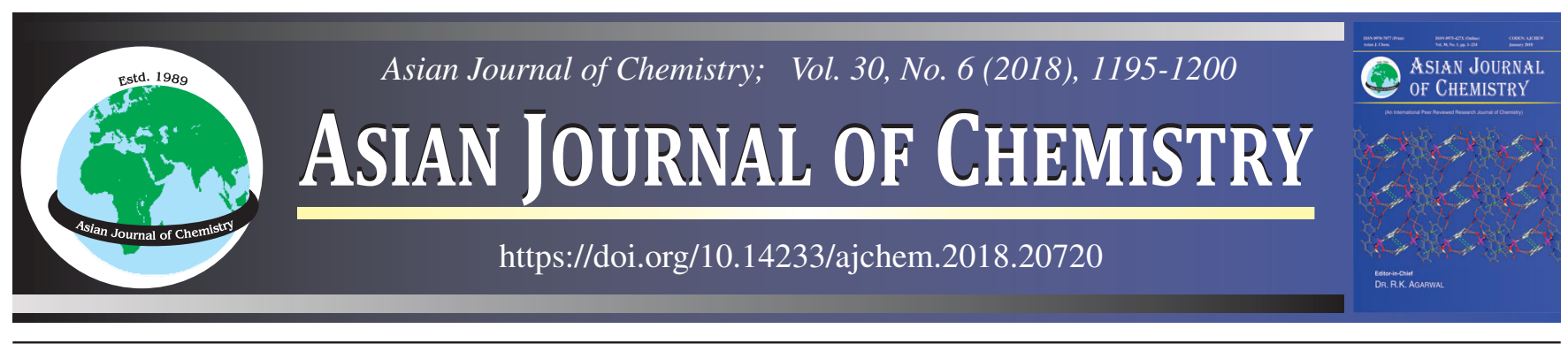

\title{
Complexation and Extraction of Transition Metal Cations by New Azodyes: Synthesis, Structure Elucidation and Binding Properties
}

Olfa Naouali ${ }^{1}$, Besma Mellah $^{2}$, Riadh Ternane $^{1}$, Lassaad Baklouti ${ }^{1,3}$, Abdelwaheb Hamdi $^{1,3}$ and Naceur Hamdi $^{3,4, *}$

${ }^{1}$ Laboratory of Applied Chemistry and Natural Substances Resources and Environment, Faculty of Sciences, University of Carthage, Zarzouna, Bizerta, 7021, Tunisia

${ }^{2}$ National Center of Researches in Material Sciences (CNRSM), Borj CedriaTechnopark, BP 73, 8027 Soliman, Tunisia

${ }^{3}$ Chemistry Department, College of Science and Arts, Qassim University, Al-Rass, Kingdom of Saudi Arabia

${ }^{4}$ Research Laboratory of Environmental Sciences and Technologies (LR16ES09), Higher Institute of Environmental Sciences and Technology, University of Carthage, Hammam-Lif, Tunisia

*Corresponding author: E-mail: naceur.hamdi@isste.rnu.tn

Received: 20 April 2017;

Accepted: 16 April 2018;

Published online: 30 April 2018;

AJC-18863

\begin{abstract}
A series of new 3-aryl(hetaryl)hydrazono-2,4-chromandiones (3a-c) were obtained in high yields, by coupling 4-hydroxycoumarin with derivatives diazonium salts, which were obtained by diazotization of aniline derivatives in presence of sodium nitrite and concentrated $\mathrm{HCl}$. The azo dyes prepared may exist in four tautomeric forms. Structures of the synthesized compounds have been investigated by means of UV, IR, ${ }^{1} \mathrm{H}$ NMR, ${ }^{13} \mathrm{C}$ NMR and elemental analysis in order to elucidate their tautomeric and isomeric structures. The results of such spectral data indicated that compound $\mathbf{3}$ exist predominantly in hydrazo structure (D). The complexation and extraction of some transition metal cations have been followed by UV-visible spectrophotometry absorption. The conductivity studies have been used in order to confirm complex's stoichiometries.
\end{abstract}

Keywords: Synthesis, Azo-hydrazone tautomerism, Coupling reaction, Complexation, Extraction.

\section{INTRODUCTION}

Azo compounds are a class of chemical compounds that are continuously receiving attention in scientific research [1-5]. Nowadays, synthetic azo compounds are widely used in different application fields, such as medicines, cosmetics, food, paints, plastics, shipbuilding, automobile industry, cable manufacture, etc. [6-9]. Furthermore, azo dye compounds are known for their medicinal importance [10,11]. The chemistry and pharmacological action of 4-hydroxy coumarin have great interest to medicinal chemistry because of its derivative possess various biological activities [12-16].

In this respect azodyes derived from coupling of diazonium salts with 4-hydroxycoumarin as coupling component are very useful as precursors for the synthesis of heterocyclic ring systems, which play an important role in pharmaceutical chemistry and dyestuff industry $[17,18]$.

In this study some new azo dyes were synthesized by coupling 4-hydroxy coumarin with diazonium salts, which obtained by the diazotization of aniline and aniline derivatives (II). The azo dyes were characterized by IR, ${ }^{1} \mathrm{H}$ NMR, UVvisible spectra. In addition, we report here the complexation and extraction properties of ligands $\mathbf{3}, \mathbf{4 b}$-c towards some transition metal cations $\left(\mathrm{Co}^{2+}, \mathrm{Cu}^{2+}, \mathrm{Zn}^{2+}\right.$ and $\left.\mathrm{Ni}^{2+}\right)$. The studies were performed by UV-visible spectrophotometry absorption and by conductimetry. The last technique was used in order to test some stoichiometries of complexes formed. The liquidliquid extraction of metallic picrate salts by ligands $\mathbf{3}, \mathbf{4 b}$-c were followed from water into dichloromethane.

\section{EXPERIMENTAL}

All reagents were obtained from Fluka and Aldrich. The purity of the products was tested in each step by TLC $\left(\mathrm{SiO}_{2}\right.$, $\mathrm{CHCl}_{3} / \mathrm{MeOH}$ and $\mathrm{THF} / \mathrm{MeOH}$ ). Melting points were determined using an Electrothermal apparatus and are uncorrected. ${ }^{1} \mathrm{H}$ NMR and ${ }^{13} \mathrm{C}$ NMR spectra were carried on a Varian Gemini $300(300 \mathrm{MHz})$ spectrometer using TMS as internal standard $(\delta=0 \mathrm{ppm})$. IR spectra were recorded on a Perkin-Elmer 398 Spectrophotometer. MS were recorded on a LC-MS-MS 8030 Shimadzu. Elemental analyses were performed on PerkinElmer 2400 elemental analyzer and the values found were within $\pm 0.3 \%$ of the theoretical values.

The UV spectra were recorded on a Perkin Elmer Lambda 24 spectrophotometer. Methanol was commercial and used 
without further purification. The supporting electrolyte used in the stability constant determinations was $\mathrm{NEt}_{4} \mathrm{Cl}$ (Acros Organics). The metal salts chosen were chlorides (Fluka). The picrate salts employed in extraction were prepared as described elsewhere [19]. The conductivity measurement was made by using Cyber Scan PC510 conductivity meter. The conductivity cell constant is $\mathrm{K}=0.9 \mathrm{~cm}$.

Stability constant measurements: The stability constant $\beta_{x y}$ corresponds to the concentration ratios $\left[\mathrm{M}_{\mathrm{x}} \mathrm{L}_{\mathrm{y}}{ }^{\mathrm{xn}+}\right] /\left[\mathrm{M}^{\mathrm{nt}}\right]^{\mathrm{x}}[\mathrm{L}]^{\mathrm{y}}$ of the general equilibrium:

$$
\mathrm{yL}=\mathrm{xM}^{1+} \rightleftharpoons \mathrm{M}_{\mathrm{x}} \mathrm{L}_{\mathrm{y}}^{\mathrm{xn}+}
$$

(where $\mathrm{M}^{\mathrm{n}+}=$ metal ion, $\mathrm{L}=$ ligand). It was determined in methanol by UV-absorption spectrophotometry at $25^{\circ} \mathrm{C}$.

The ionic strength has been maintained at $0.01 \mathrm{~mol} \mathrm{~L}^{-1}$ using $\mathrm{Et}_{4} \mathrm{NCl}$. The UV spectra were recorded between 220 $\mathrm{nm}$ and $350 \mathrm{~nm}$. The concentration of ligand is varying between $4 \times 10^{-5}$ and $5 \times 10^{-5} \mathrm{~mol} \mathrm{~L}^{-1}$. Generally, the metal to ligand ratio $R$ at the end of the titration did not exceed 15 and the equilibriums were quasi-instantaneous. The addition of the metal salts to the ligand solution induced spectral changes, significant enough to be treated by the program "Letagrop" [20]. Best values of stability constants $\beta_{\mathrm{xy}}$ of each complex and the molar absorptivity coefficients of various wavelengths are deduced from the best fit between the experimental $\left(\mathrm{A}_{\exp }\right)$ and calculated $\left(\mathrm{A}_{\text {cal }}\right) \mathrm{UV}$ spectra. The best fit is corresponding to the lowest value of $\mathrm{U}\left[\mathrm{U}=\Sigma\left(\mathrm{A}_{\mathrm{cal}}-\mathrm{A}_{\mathrm{exp}}\right)^{2}\right]$. The $\beta_{\mathrm{xy}}$ values correspond to the arithmetic means of at least three independent experiments.

Liquid-liquid extraction: The extraction of transition metal picrates from water into dichloromethane were performed according to procedures described in the literature $[21,22]$. Equal volumes $(5 \mathrm{~mL})$ of neutral aqueous solution of metal picrate $\left(3 \times 10^{-4} \mathrm{~mol} \mathrm{~L}^{-1}\right)$ and $\mathrm{CH}_{2} \mathrm{Cl}_{2}$ solution $(5 \mathrm{~mL})$ of coumarine derivatives $\left(3 \times 10^{-4} \mathrm{~mol} \mathrm{~L}^{-1}\right)$ were mixed, magnetically shaken in a thermo-regulated water bath at $25^{\circ} \mathrm{C}$ for $30 \mathrm{~min}$ and then left standing for 2 to $6 \mathrm{~h}$ in order to obtain a complete separation of both phases. The concentration of metal picrate remaining in the aqueous phase was deduced from the measurement of the absorbance (A) at $355 \mathrm{~nm}$. The percentage of extraction $(\% \mathrm{E})$ was calculated from the following expression in which $\mathrm{A}_{0}$ is the absorbance of the aqueous solution of a blank experiment without ligand:

$$
\mathrm{E}(\%)=100\left(\mathrm{~A}_{0}-\mathrm{A}\right) / \mathrm{A}_{0}
$$

General synthesis of 4-hydroxy-3-(substituted phenyldiazenyl)-2H-chromen-2-one (3-4): A cold solution of aryldiazonium salt $(4 \mathrm{mmol})$ was prepared by adding a sodium nitrite solution ( $0.4 \mathrm{~g}, 6 \mathrm{mmol}$, dissolved in $2 \mathrm{~mL}$ water) to a pre-cooled solution of arylamine hydrochloride $(4 \mathrm{mmol}$ of either of the appropriate aniline derivatives 2 in $2 \mathrm{~mL}$ of $6 \mathrm{M}$ hydrochloric acid) with continuous stirring. The resulting solution of the aryl diazonium salt was then added carefully to a cold solution of 4-hydroxy coumarin $(4 \mathrm{mmol})$ in ethanol $(40 \mathrm{~mL})$ containing sodium hydroxide $\left(0.66 \mathrm{~g}\right.$ in $\left.2 \mathrm{~mL} \mathrm{H}_{2} \mathrm{O}\right)$. The coloured products obtained were filtered, washed with water and finally the products were dried. The entire product individually recrystallized from $50 \%$ ethanol.
3-[(2-Oxo-1.2-dihydro-pyrimidin-4-yl)-hydrazono]chromane-2.4-dione (3): Yellow solid, Yield: $85 \%$; UV-visible ( $\lambda_{\max }$ in DMSO): $324 \mathrm{~nm}$, FT-IR $\left(\mathrm{KBr}, \nu_{\max }, \mathrm{cm}^{-1}\right): 3363(-\mathrm{NH})$, $1646\left(\mathrm{C}=\mathrm{O}\right.$, lactone), $1584(\mathrm{~N}=\mathrm{N}), 1600($ Aryl $\mathrm{C}=\mathrm{C}) .{ }^{1} \mathrm{H}$ NMR (300 MHz, DMSO- $d_{6}, \delta / \mathrm{ppm}$ ): 7.35-8.36 (m, 6H, Ar-H), 10.80 (s, NH); ${ }^{13} \mathrm{C}$ NMR (75 MHz, DMSO- $\left.d_{6}, \delta / \mathrm{ppm}\right): 158.2\left(\mathrm{C}_{2}\right)$, $154.7\left(\mathrm{C}_{3}\right), 188.7\left(\mathrm{C}_{4}\right), 164.2\left(\mathrm{C}_{1^{\prime}}\right), 97.2\left(\mathrm{C}_{2^{\prime}}\right), 131.3\left(\mathrm{C}_{3^{\prime}}\right), 161.2$ $(\mathrm{C}=\mathrm{O})$, 121.9-130.1 (Carom). Calc. for $\mathrm{C}_{13} \mathrm{H}_{8} \mathrm{~N}_{3} \mathrm{O}_{4}$ : C 57.782 $\% ; \mathrm{H}, 2.984 \%, \mathrm{~N} 15.550 \%$. Found: C 57.8; H, 2.3, N, 15.6

4-Hydroxy-3-(2,4,6-trimethylphenyldiazenyl)-2Hchromen-2-one (4b): Yellow solid, Yield: $81 \%$; UV-visible ( $\lambda_{\max }$ in DMSO): $325 \mathrm{~nm}$, FT-IR $\left(\mathrm{KBr}, \nu_{\max }, \mathrm{cm}^{-1}\right): 3356(-\mathrm{NH})$, $1636\left(\mathrm{C}=\mathrm{O}\right.$, lactone), $1584(\mathrm{~N}=\mathrm{N}), 1600($ Aryl $\mathrm{C}=\mathrm{C}) .{ }^{1} \mathrm{H}$ NMR (300 MHz, DMSO- $\left.d_{6}, \delta / \mathrm{ppm}\right): 7.32-8.22(\mathrm{~m}, 6 \mathrm{H}, \mathrm{Ar}-\mathrm{H}), 12.70$ (s, NH). ${ }^{13} \mathrm{C}$ NMR $\left(75 \mathrm{MHz}, \mathrm{DMSO}-d_{6}, \delta / \mathrm{ppm}\right): 12.3\left(\mathrm{CH}_{3}\right)$, $12.4\left(\mathrm{CH}_{3}\right), 21.4\left(\mathrm{CH}_{3}\right), 158.2\left(\mathrm{C}_{2}\right), 154.4\left(\mathrm{C}_{3}\right), 188.5\left(\mathrm{C}_{4}\right)$, 121.8-134.7 (Carom). Calc. for $\mathrm{C}_{18} \mathrm{H}_{16} \mathrm{~N}_{2} \mathrm{O}_{3}: \mathrm{C} 70.117 \%$; $\mathrm{H}$, $5.230 \%, \mathrm{~N} 9.085 \%$. Found: C 70.2; H, 5.3, N, 8.9

4-Hydroxy-3-(4-chloromethylphenyldiazenyl)-2Hchromen-2-one (4c): Yellow solid, yield $=90 \%$; UV-visible ( $\lambda_{\max }$ in DMSO): $324 \mathrm{~nm}$, FT-IR $\left(\mathrm{KBr}, \nu_{\max }, \mathrm{cm}^{-1}\right): 3392(-\mathrm{NH})$, $1654(\mathrm{C}=\mathrm{O}$, lactone $), 1070(\mathrm{C}-\mathrm{O}), 1560(\mathrm{~N}=\mathrm{N}), 1326\left(\mathrm{C}_{\text {arom }}{ }^{-}\right.$ $\mathrm{N}) .{ }^{1} \mathrm{H} \mathrm{NMR}\left(300 \mathrm{MHz}, \mathrm{DMSO}-d_{6}, \delta / \mathrm{ppm}\right): 5.61\left(\mathrm{~s}, 2 \mathrm{H}, \mathrm{CH}_{2}\right)$, 7.36-8.19 (m, 8H, Ar-H), 12.34 (s, NH). ${ }^{13} \mathrm{C}$ NMR (75 MHz, DMSO- $\left.d_{6}, \delta / \mathrm{ppm}\right): 50.4\left(\mathrm{CH}_{2}-\mathrm{Cl}\right), 158.1\left(\mathrm{C}_{2}\right), 154.5\left(\mathrm{C}_{3}\right)$, 187.5 $\left(\mathrm{C}_{4}\right), 115.3-134.7$ (Carom). Calc. for $\mathrm{C}_{16} \mathrm{H}_{11} \mathrm{~N}_{2} \mathrm{O}_{3} \mathrm{Cl}: \mathrm{C}$ $61.060 \%$; H, $3.523 \%$, N 8.901 \% Found: C 61.2; H, 3.6, N, 8.8.

\section{RESULTS AND DISCUSSION}

As a starting point for our investigation, we first examined the coupling reaction of 4-hydroxycoumarin with diazonium salt of aniline derivatives 2a-c. Thus, coupling of diazonium salt $\mathbf{2}$ with hydroxycoumarin in aqueous ethanol in the presence of a buffered sodium hydroxide solution gave 4-hydroxy-3(substituted phenyldiazenyl)-2H-chromen-2-one $\mathbf{3}$, as the only isolable product, in excellent yield (Scheme-I). The crude products recrystallized from $50 \%$ ethanol while some compound from mixture of ethanol and DMF. The structures of the isolated products 3-4 were established by their spectroscopic (UV, IR, ${ }^{1} \mathrm{H}$ NMR, ${ }^{13} \mathrm{C}$ NMR and MS) data and elemental analyses.

The assignment of the IR absorption bands was carried out by known procedure [23]. In which the spectral region is divided to three main regions mainly; 4000-2600, 1700-1200 and $1000-625 \mathrm{~cm}^{-1}$.

In first region, the broad band appearing at 3356-3172 $\mathrm{cm}^{-1}$ in all the compounds corresponds to the stretching vibrations of the $\mathrm{NH}$ and $\mathrm{CH}$ groups. Two bands at $2956-2780 \mathrm{~cm}^{-1}$ are attributed to asym and sym stretching vibrations of the $\mathrm{CH}$ groups. This was recognized by Coblentz [24] and Bonino [25] who pointed out that the characteristic C-H bands of aromatic and aliphatic compounds occur at different recognizable positions in this region. Azo dye $\mathbf{4 c}$ shows a band at 2520 $\mathrm{cm}^{-1}$ due to the stretching vibration of the $\mathrm{CH}_{3}$ groups.

In the second region, the bands at 1652 and 1528-1500 $\mathrm{cm}^{-1}$ can be attributed to the stretching vibrations of the $\mathrm{C}=\mathrm{O}$ and the $\mathrm{C}=\mathrm{C}$ ring absorption bands, respectively. The stretching vibration of $\mathrm{N}=\mathrm{N}$ bond gives rise to a band at $1446 \mathrm{~cm}^{-1}$ while 
<smiles>Nc1cc[nH]c(=O)n1</smiles>

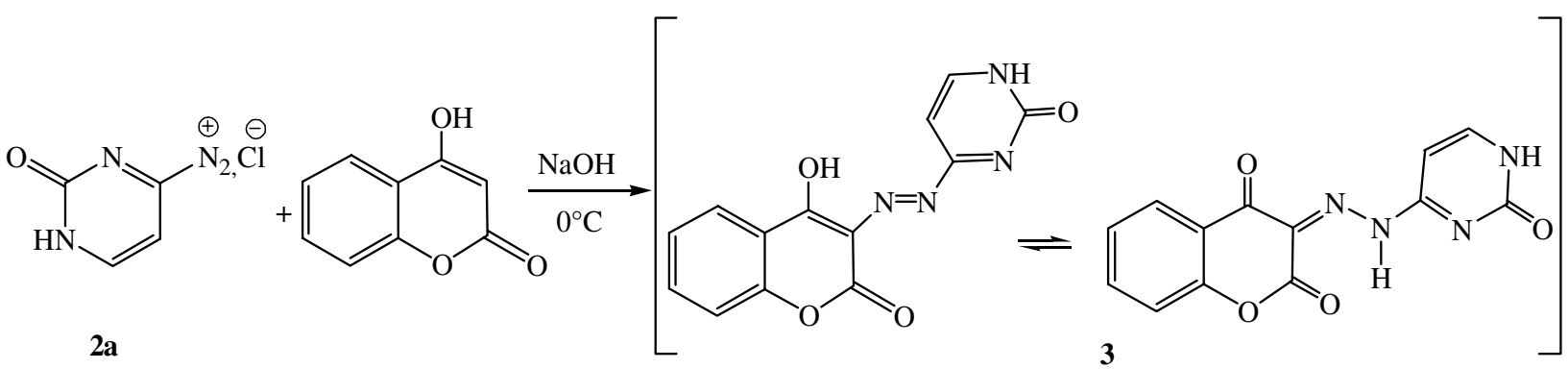

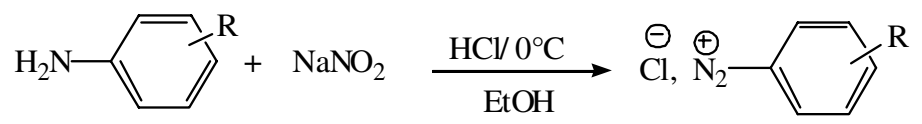<smiles></smiles>

2b-c

$$
\begin{aligned}
& b: \mathrm{R}=2.4 .6-\mathrm{CH}_{3} \\
& \text { c: } \mathrm{R}=\boldsymbol{p}-\mathrm{Cl}-\mathrm{CH}_{2}
\end{aligned}
$$

4b-c

Scheme-I: Coupling reaction of hydroxycoumarin with benzene diazonium chloride (2)

the bending vibration band of the C-O group appears at 1040 $\mathrm{cm}^{-1}$.

In the third region, most of the strong bands appearing in the range $1000-625 \mathrm{~cm}^{-1}$ are due to the out-of-plane deformation vibration of the hydrogen atoms present in the ring. The band position can be discussed in terms of the number of adjacent hydrogen atoms.

Azo dyes 3-4 were scanned through wave numbers ranged between $4000-400 \mathrm{~cm}^{-1}$ using $\mathrm{KBr}$ disk. The main absorption bands of the dyes 3-4 are shown in Table-1.

The ${ }^{1} \mathrm{H}$ NMR spectra of compound $\mathbf{4 c}$ measured in DMSO$d_{6}$ at $25^{\circ} \mathrm{C}$ showed a singlet at $5.61 \mathrm{ppm}$ due to the two protons of $\mathrm{CH}_{2}$. Multiple signals of the aromatic protons appear in the range 7.36 to $8.19 \mathrm{ppm}$. The signal of the $\mathrm{NH}$ group appeared at $\delta=12.34 \mathrm{ppm}$.

The ${ }^{13} \mathrm{C}$ NMR spectrum of this product in DMSO- $d_{6}$ displayed signals in agreement with the proposed structures.

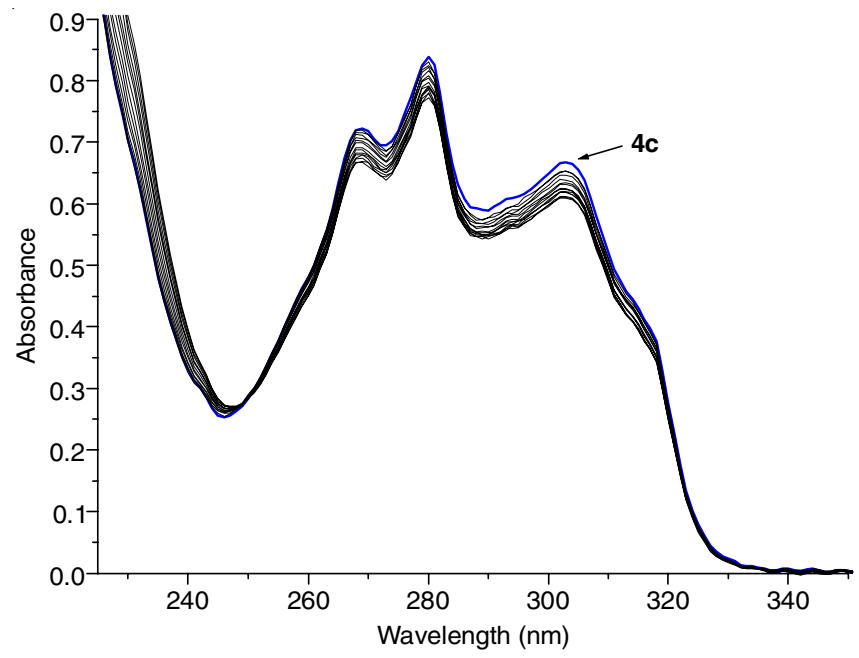

Fig. 1. UV absorption spectra on complexation of $\mathrm{Co}^{2+}$ with $\mathbf{4 c}$, in methanol, $\left(0 \leq \mathrm{R}_{\mathrm{ML}} \leq 1.7\right)$ at $25^{\circ} \mathrm{C}$

MAIN ABSORPTION BANDS AND THE POSSIBLE FUNCTIONAL GROUPS IN DYES 3-4

\begin{tabular}{lccc}
\hline \multicolumn{1}{c}{ Absorption bonds } & & Wavenumber $\left(\mathrm{cm}^{-1}\right)$ \\
\cline { 2 - 4 } & Dye $\mathbf{3}$ & Dye 4b & Dye 4c \\
\hline -NH stretching & 3363 & 3356 & 3410 \\
Aryl =C-H stretching & 3051 & 3172 & 3060 \\
Aliphatic -C-H stretching might be caused by trace of & 2925 & 2956 & 2930 \\
Aryl C=C stretching & 1600 & 1652 & 1645 \\
-N=N- stretching & 1584 & 1586 & 1454 \\
\hline
\end{tabular}


The spectrum of compound $\mathbf{4} \mathbf{c}$ showed besides the signals due to aromatic, $\mathrm{CH}_{2}$ carbons, three characteristic signals at $\delta=$ 99.05, 101.1 and $140.75 \mathrm{ppm}$ attributable to the carbon atom at position 2, 3 and 4, respectively.

${ }^{1} \mathrm{H}$ NMR spectra of dye $\mathbf{3}$ and dye $\mathbf{4 b}$ exhibit one broad peak at 10.80 and 12.70 , respectively, which were attributed to $\mathrm{NH}$ protons. These results show that the dyes may exist as a mixture of several tautomeric forms in DMSO.

The purity of the compounds 3-4 was firstly confirmed by m.p. constancy. Their elemental analysis (Table-2) showed satisfactory agreement with the expected tentative formula.

The azo dyes 3-4 may exist in various tautomeric forms, four of them are shown in Scheme-II. Hence, the ${ }^{1} \mathrm{H}$ NMR spectra of dyes exhibit a broad signal near $12.6 \mathrm{ppm}$, indicating a NH proton resonance of the hydrazone form.
The dyes may exist in four possible tautomeric forms, namely two azo-enol forms $\mathrm{A}$ and $\mathrm{B}$, the hydrazone-keto form $\mathrm{C}$ and the azo-keto form D, as shown in Scheme-II.

The coupling mechanism of organic reaction is summarized in the Scheme-III.

\section{Complexation and extraction of transition metal cations} by azodyes 3-4

Spectrophotometric study: The complexation of divalent metal cations $\left(\mathrm{Co}^{2+}, \mathrm{Cu}^{2+}, \mathrm{Zn}^{2+}\right.$ and $\left.\mathrm{Ni}^{2+}\right)$ by azodyes $3,4 \mathbf{b}-\mathbf{c}$ was interpreted by spectral variations throughout the titration of azodyes solution by metal solution. Generally, a decrease of absorbances was observed as shown on Fig. 1, which corresponds to the complexation of $\mathrm{Co}^{2+}$ by ligand $\mathbf{4 c}$.

The treatment of UV spectra letagrop [20] allowed us to detect the stoichiometry of the complex formed and to calculate<smiles>C=C/N=N/c1c(O)c2ccccc2oc1=O</smiles>

(A)<smiles>O=c1c(/N=N/[Al])c(O)oc2ccccc12</smiles>

(B)<smiles>O=C1Oc2ccccc2C(=O)C1N=N[Al]</smiles>

(C)<smiles>O=C1Oc2ccccc2C(=O)/C1=N/NC(=O)c1ccccc1</smiles>

(D)

Scheme-II: Possible tautomeric forms of dyes 3-4

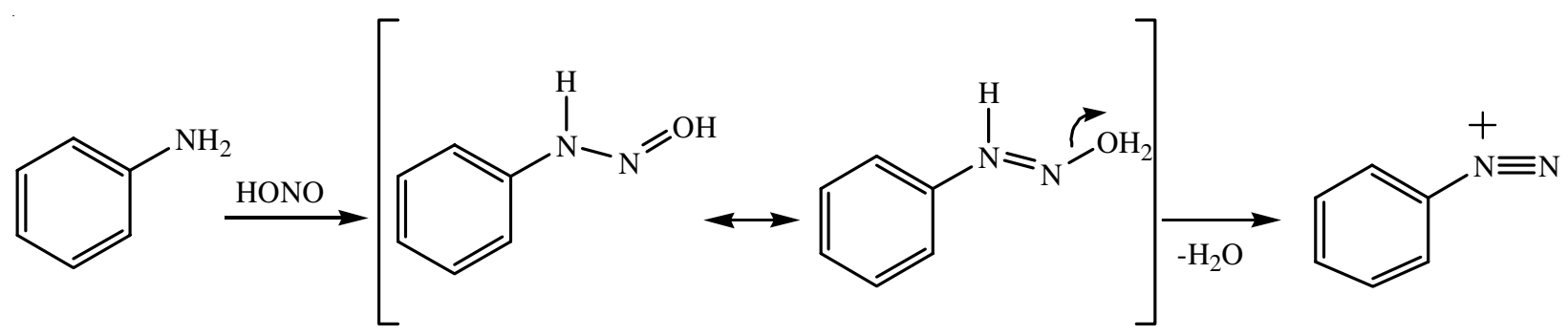<smiles></smiles><smiles>O=C1Oc2ccccc2C(=O)/C1=N\N[125I]</smiles>

Scheme-III: Proposed mechanism of the coupling reaction 
TABLE-2

ELEMENTAL ANALYSIS OF THE AZO COMPOUND UNDER INVESTIGATION

\begin{tabular}{|c|c|c|c|c|c|c|}
\hline \multirow{2}{*}{ Comp. } & \multirow{2}{*}{ Colour } & \multirow{2}{*}{ m.p. $\left({ }^{\circ} \mathrm{C}\right)$} & \multicolumn{3}{|c|}{ Elemental analysis (\%) } & \multirow{2}{*}{ m.f. } \\
\hline & & & $\mathrm{C}$ & $\mathrm{H}$ & $\mathrm{N}$ & \\
\hline 3 & Red & 185 & 57.8 & 2.1 & 15.6 & $\mathrm{C}_{13} \mathrm{H}_{8} \mathrm{~N}_{3} \mathrm{O}_{4}$ \\
\hline $4 b$ & Brown & 190 & 70.2 & 5.3 & 8.9 & $\mathrm{C}_{18} \mathrm{H}_{16} \mathrm{~N}_{2} \mathrm{O}_{3}$ \\
\hline $4 c$ & Orange red & 195 & 61.2 & 3.6 & 8.8 & $\mathrm{C}_{16} \mathrm{H}_{11} \mathrm{~N}_{2} \mathrm{O}_{3} \mathrm{Cl}$ \\
\hline
\end{tabular}

the logarithms of its stability constant $\log \beta_{\mathrm{xy}}$. All these results are given in Table-3.

TABLE-3

STABILITY CONSTANTS $\log \beta_{\mathrm{xy}}$ OF COMPLEXES OF TRANSITION METAL CATIONS, IN METHANOL AT $25^{\circ} \mathrm{C}, \mathrm{I}=10^{-2} \mathrm{M},\left(0.01 \leq \sigma_{\mathrm{n}-1} \leq 0.16\right)$

\begin{tabular}{cccccc}
\hline & $\mathrm{M}: \mathrm{L}$ & $\mathrm{Co}^{2+}$ & $\mathrm{Ni}^{2+}$ & $\mathrm{Cu}^{2+}$ & $\mathrm{Zn}^{2+}$ \\
\hline $\mathbf{3}$ & $1: 1$ & 3.93 & 3.97 & 4.18 & 3.95 \\
$\mathbf{4 b}$ & $1: 1$ & 3.81 & 3.85 & 4.08 & 3.83 \\
$\mathbf{4 c}$ & $1: 1$ & 3.77 & 3.79 & 4.01 & 3.81 \\
\hline
\end{tabular}

The digital processing reveals the formation of ML species in all cases of metal/ligand systems.

The values of the stability constants shift between 3.77 and 4.18 logarithmic units. The three ligands exhibit same behaviour in terms of affinity, increasing from cobalt to copper and then decreasing to zinc. This order followed the IrvingWilliams rules [26]. Although the best values are noticed with copper, no significant selectivity was detected. As comparison between three azodyes derivatives $\mathbf{3}, \mathbf{4 b}$-c containing both an oxygen site (hard base) and nitrile site (soft base), $\mathbf{3}$ has a slightly higher affinity which could be explained by the presence in addition of $H$-pyrimidin-2-one group in the molecule increasing its affinity towards transition metal cations (Fig. 2). The presence of $s p^{2}$ nitrogen atoms having a localized electron pair is coordinating with the metal through $\sigma$-donor interaction. The $s p^{2}$ nitrogen atoms in the heterocyclic group have an intermediate character between the soft characters of $s p^{3}$ nitrogen atoms which complex the softer metals such as transition metals. Besides, such cations as $\mathrm{Co}^{2+}$ and $\mathrm{Cu}^{2+}$, with near ionic radius values, have different stability. So the ionophoric properties of ligands do not just depend on the cation size but also other phenomena such as the coordination of cation, study areas, basic character/acid, hard/soft. It should be noted that the chloromethyl group $(\mathbf{4 c})$ slightly reduces the complexing power compared to its counterpart tri methyl group (4b).

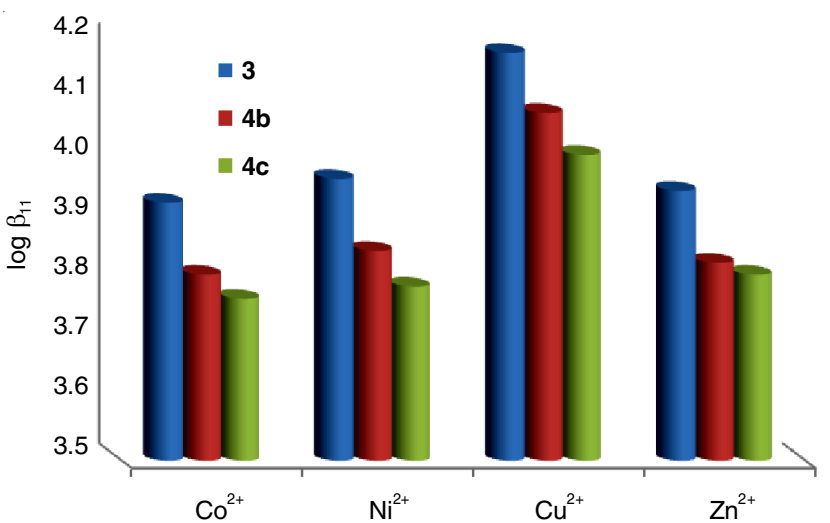

Fig. 2. Stability constants $\log \beta_{11}$ (determined in methanol) for some transition metal cations with $\mathbf{3}, \mathbf{4 b}-\mathbf{c}$
Fig. 2 makes in evidence the increase of complex stabilities in favour of copper. These results are in agreement with with some coumarine phthalonitrile derivatives in both acetonitrile and methanol [27,28].

Conductimetric study: While the cation complexation by a neutral azodyses is not expected to dramatically alter the molar conductivity, the difference can be usually detected and so the measurement of conductance during the titration of the ligand by the metal solution can be a useful way to establish the stoichiometry of different species formed in solution. Thus, this procedure was followed to obtain preliminary estimates of the metal:ligand ratio $[19,29]$.

As results, the stoichiometries 1:1 of complexes formed by compounds $\mathbf{3}, \mathbf{4 b - c}$, were confirmed by conductimetric titration as shown on Fig. 3 which illustrate the stoichiometry 1:1 of complex [Cu.4b] $]^{2+}$ (Fig. 3).

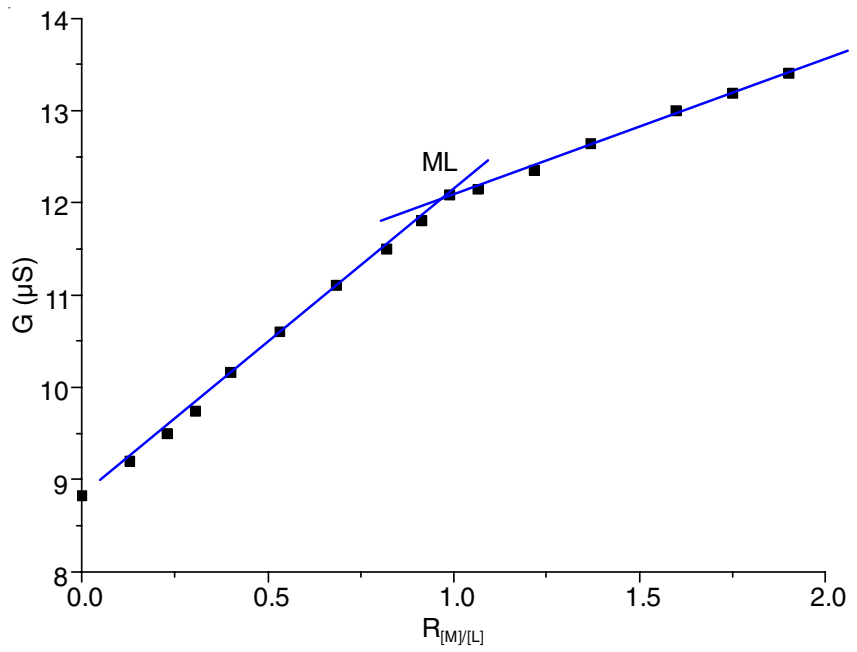

Fig. 3. Complexation of $\mathrm{Cu}^{2+}$ by $\mathbf{4 b}$, in methanol

Extraction study: All values of \% $\mathrm{E}$ are given in Table- 4 . The percentages of extraction shift between 5 and $38 \%$. Same behaviour as found in the complexation studies, affinities of the three azodyes increase towards copper. Although the heterogeneous environment, 3, 4b-c keep same behaviour towards divalent cations.

\begin{tabular}{ccccc}
\multicolumn{5}{c}{ TABLE-4 } \\
\multicolumn{5}{c}{ PERCENTAGE OF EXTRACTION $(\%$ E) OF } \\
\hline \multicolumn{5}{c}{ TRANSITION METAL PICRATES BY $\mathbf{3 , 4 b - c}$ AT $25^{\circ} \mathrm{C}$} \\
\hline $\mathrm{E}(\%)$ & $\mathrm{Co}^{2+}$ & $\mathrm{Ni}^{2+}$ & $\mathrm{Cu}^{2+}$ & $\mathrm{Zn}^{2+}$ \\
\hline $\mathbf{3}$ & 19 & 21 & 36 & 32 \\
$\mathbf{4 b}$ & 16 & 20 & 38 & 29 \\
$\mathbf{4 c}$ & 9 & 11 & 14 & 12 \\
\hline
\end{tabular}

The results show that no ligands have a high affinity for extraction with respect to the used cations under the operating 
conditions. However, ligand $\mathbf{4 c}$ is the least extractant in the series of azodyes. Regarding the used cations, $\mathrm{Cu}^{2+}$ is the best extracted one (Fig. 4).

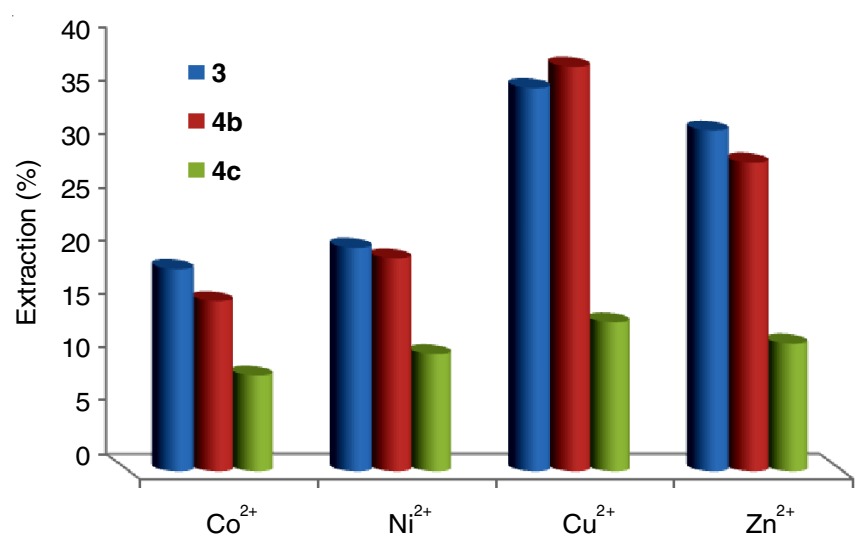

Fig. 4. Trends of the extraction percentages (\% E) from water into dichloromethane of some transition metal picrates by $\mathbf{3}, \mathbf{4 b - c}$

\section{Conclusion}

Three new azo dyes 3-4 including coumarin ring were synthesized and their physico-chemical charactetics were determined. The spectroscopic data of the prepared dyes has provided decisive evidence that such compounds exist predominantly in hydrazo structure (D) as a mixture of $\mathrm{Z}$ and Eisomer with ratio $\sim 85: 16$. Furthermore, the complexation study followed by spectrophotometry UV-visible has shown the formation of mononuclear species with transition metal cations. The stoichiometry ML was confirmed by conductimetry. The three compounds have shown similar behaviour in terms of their affinity towards transition metal cations and the best values of stability constants were observed in favour of $\mathrm{Cu}^{2+}$.

\section{ACKNOWLEDGEMENTS}

This work was carried out with the financial aid received from Qassim University in KSA through project No. 3181.

\section{REFERENCES}

1. B. Kirkan and R. Gup, Turk. J. Chem., 32, 9 (2008).

2. A.M. Metwally, S. Bondock, S.I. El-Desouky and M.M. Abdou, Am. J. Chem., 2, 347 (2012)

3. R. Medyouni, W. Elgabsi, O. Naouali, A. Romerosa, A. Sulaiman Al-Ayed, L. Baklouti and N. Hamdi, Spectrochim. Acta A Mol. Biomol. Spectrosc., 167, 165 (2016);

https://doi.org/10.1016/j.saa.2016.04.045.

4. Y. Arfaoui, A.S. Al-Ayed, R.B. Said and A.I. Hamed, Int. J. Chem., 5, 73 (2013); https://doi.org/10.5539/ijc.v5n4p73.

5. I. Sviben, N. Galic, V. Tomisic and L. Frkanec, New J. Chem., 39, 6099 (2015); https://doi.org/10.1039/C5NJ00805K
6. S.I. Klink, P.O. Alink, L. Grave, F.G.A. Peters, J.W. Hofstraat, F. Geurts and F.C.J.M. Van Veggel, J. Chem. Soc. Perkin Trans. II, 363 (2001); https://doi.org/10.1039/b007704f.

7. G. Gong, X. Gao, J. Wang, D. Zhao and H.S. Freeman, Dyes Pigments, 53, 109 (2002); https://doi.org/10.1016/S0143-7208(02)00010-4.

8. D. Hinks, H.S. Freeman, M. Nakpathom and J. Sokolowska, Dyes Pigments, 44, 199 (2000); https://doi.org/10.1016/S0143-7208(99)00078-9

9. K. Wojciechowski, A. Wyrebak and J. Gumulak, Dyes Pigments, 56, 99 (2003); https://doi.org/10.1016/S0143-7208(02)00130-4.

10. H.G. Garg and C. Prakash, J. Med. Chem., 15, 435 (1972); https://doi.org/10.1021/jm00274a035.

11. A. Khalid, M. Arshad and D.E. Crowley, Appl. Microbiol. Biotechnol., 78, 361 (2008); https://doi.org/10.1007/s00253-007-1302-4.

12. Z.H. Chohan, A.U. Shaikh, A. Rauf and C.T. Supuran, J. Enzyme Inhib. Med. Chem., 21, 741 (2006); https://doi.org/10.1080/14756360600810340.

13. M. Velascovelazquez, Cancer Lett., 198, 179 (2003); https://doi.org/10.1016/S0304-3835(03)00333-1.

14. A.C. Luchini, P. Rodrigues-Orsi, S.H. Cestari, L.N. Seito, A. Witaicenis, C.H. Pellizzon and L.C. Di Stasi, Biol. Pharm. Bull., 31, 1343 (2008); https://doi.org/10.1248/bpb.31.1343.

15. B.S. Kirkiacharian, E. De Clercq, R. Kurkjian and C. Pannecouque, $J$. Pharm. Chem., 42, 265 (2008); https://doi.org/10.1007/s11094-008-0103-0.

16. O.I. Aruoma and S.L. Cuppett, Arch. Ital. Sci. Farmacol., 9, 61 (1959).

17. M.A. Metwally, S. Bondock, S.I. El-Desouky and M.M. Abdou, J. Korean Chem. Soc., 56, 82 (2012); https://doi.org/10.5012/jkcs.2012.56.1.082.

18. M.A. Metwally, S. Bondock, S.I. El-Desouky and M.M. Abdou, J. Korean Chem. Soc., 56, 348 (2012); https://doi.org/10.5012/jkcs.2012.56.3.348.

19. A. Casnati, A. Pochini, R. Ungaro, F. Ugozzoli, F. Arnaud, S. Fanni, M.-J. Schwing, R.J.M. Egberink, F. de Jong and D.N. Reinhoudt, J. Am. Chem. Soc., 117, 2767 (1995); https://doi.org/10.1021/ja00115a012.

20. L.G. Sillén, B. Warnqvist, V. Meisalo and P. Kelly, Acta Chem. Scand., 22, 3032 (1968); https://doi.org/10.3891/acta.chem.scand.22-3032.

21. C. Pedersen, J. Am. Chem. Soc., 93, 391 (1970); https://doi.org/10.1021/ja00705a606.

22. H.K. Frensdorff, J. Am. Chem. Soc., 92, 4684 (1971); https://doi.org/10.1021/ja00748a006.

23. W. Collier, T.P. Schultz and F. Kalasinsky, Holzforschung, 46, 523 (1992); https://doi.org/10.1515/hfsg.1992.46.6.523.

24. W.W. Coblentz, Investigation of Infrared Spectra, Comegle Institute, Washington (1905).

25. G.B. Bonino, Trans. Faraday Soc., 25, 876 (1929); https://doi.org/10.1039/tf9292500876.

26. H. Irving and R.J.P. Williams, J. Chem. Soc., 3192 (1953); https://doi.org/10.1039/jr9530003192.

27. O. Naouali, B. Mellah, R. Medyouni, N. Hamdi and L. Baklouti, Eur. J. Chem., 6, 337 (2015); https://doi.org/10.5155/eurjchem.6.3.337-341.1271.

28. R. Medyouni, O. Naouali, N. Hamdi, F. Zagrouba and L. Baklouti, $J$. Adv. Chem., 11, 3512 (2015).

29. W. Thabet, L. Baklouti, R. Zieba and S. Parola, J. Incl. Phenom. Macrocycl. Chem., 73, 135 (2012); https://doi.org/10.1007/s10847-011-0033-4. 